\title{
ANALYSIS OF THE POTENTIAL INCOME OF TOBACCO (Nicotiana Tabacum L.) FARMERS IN LIMAPULUH KOTA REGENCY OF WEST SUMATERA PROVINCE
}

\author{
Dara Latifa $^{1}$, Ispinimiartriani ${ }^{2}$, Soemarsono $^{3}$, M. Syakib Sidqi $^{4}$ \\ Agricultural State Polytechnic of Payakumbuh, Payakumbuh \\ Correspondence Address: Jl. Raya Negara KM. 7 Tanjung Pati 26271, Tel/Fax \\ (0752) $7754192 /(0752) 7750220$ \\ E-mail: ${ }^{1)}$ dara.latifa@politanipyk.ac.id, ${ }^{2)}$ soemarsono@politanipyk.ac.id
}

\begin{abstract}
West Sumatra is one of the tobacco producing provinces in Indonesia and the largest producer is Limapuluh Kota Regency. The majority of the population of Limapuluh Kota Regency livelihoods as farmers and one of them is tobacco farmers. The profession of tobacco farmers is often a seasonal profession for the community. Because the price, production and area of tobacco land are fluctuating. This research aims to find out the potential of tobacco farming to farmers' incomes in terms of income when compared to UMP West Sumatra, business feasibility, minimum land area and price. Research methods are survey using questionnaire instruments. The data used is primary and secondary data. Data analysis methods use income analysis, $Z$ test comparison analysis, feasibility analysis, minimum land area and price. The results showed that the analysis of wet and dry tobacco farm income has the potential to provide benefits for farmers indicated by the value of the $R / C$ feasibility analysis > 1. Comparative analysis with UMP West Sumatra using Test $Z$ showed if the $H 1$ hypothesis was accepted. Analysis of land area and minimum selling price shows that land area and price level appropriate to achieve income level in accordance with UMP West Sumatra.
\end{abstract}

Keywords: Income, Minimum Wage, Tobacco, Z Test

\section{INTRODUCTION}

Tobacco is one of the most important plantation commodities in Indonesia. The role of tobacco and tobacco products industry in socio-economic communities is the producer of excise and foreign exchange, employment providers and as a source of income for farmers, workers, traders and regional income (Hasan \& Darwanto, 2017). Tobacco producing areas include North Sumatra, West Sumatra, Bengkulu, South Sumatra, Central Java and East Java (Suwarto et al., 2014).

West Sumatra is one of the tobacco producing provinces in Indonesia with a total land area in 2020 of 482.50 ha and production reaching 401.96 tons. Limapuluh Kota regency is the largest tobacco producer of West Sumatra indicated by the largest tobacco land area and the highest production of 247.50 ha and 178.96 tons in 2020 (BPS, 2021b). The center of tobacco production of Limapuluh Kota Regency is in two sub-districts namely Bukit Barisan and Situjuh Limo Nagari where the resulting tobacco production reaches 117.56 tons, which is $66 \%$ of the total production of Limapuluh Kota Regency (BPS, 2021a).

The potential of Limapuluh Kota Regency as a center of tobacco production in West Sumatra is already known such as Guntung and Baruah Gunung tobacco in Bukik Barisan District, tobacco in Harau District, Situjuah Limo Nagari District, and Lareh Sago Halaban District. This great potential makes local governments aggressively make business cooperation in the tobacco commodity sector. Cooperation with business partners is expected to improve the welfare of farmers (Haluan, 2018).

Limapuluh Kota Regency gets 3 varieties of tobacco cultivated by farmers, namely Rudau Teleng variety, Rudau Sendok variety and Taram variety that belongs to real tobacco / rajangan. As for the variety that is widely cultivated is the Rudau Teleng variety. While in general, tobacco 
consists of 4 types, namely cigar tobacco, pipe tobacco, cigarette tobacco and native tobacco / rajangan. Real tobacco consists of many varieties according to their development area (Suwarto et al., 2014). In cultivation techniques, tobacco farmers use monoculture planting patterns and there is also polyculture.

The majority of the residents of Limapuluh Kota Regency livelihood as farmers and one of them tobacco farmers. But the profession as a tobacco farmer is often a seasonal profession for the community. This is because tobacco prices fluctuate. When tobacco prices are high, dominant societies cultivate tobacco. But there are also farmers who are consistent to keep cultivating tobacco despite the low price (Aini et al., 2019).

Fluctuations in tobacco production are caused by fluctuations in the demand levels of middlemen and weather conditions. The level of welfare of farmers is often associated with the state of farming business reflected in the income level of farmers. Marketing of tobacco products farmers usually sell in the form of leaves or stems and some sell in the form of dried leaves. Tobacco farming is relatively small in scale and the dependence on selling prices that fluctuate every time will affect farmers'productions and farmers' incomes (Suhirman \& Yusup, 2017). Furthermore, the problem faced by tobacco farmers is that farmers only act as price takers in tobacco marketing and weak institutional consolidation that is unable to help farmers change their position as price makers.

Land area for tobacco farming over the past three years has also fluctuated and even tends to decrease. Following the Indonesian Tobacco Farmers Association (APTI) Limapuluh Kota Regency in 2018, the area of tobacco farming land, especially in Bukik Barisan and Situjuah Limo Nagari districts amounted to $333 \mathrm{Ha}$ and $73 \mathrm{Ha}$. But there is a decrease in 2020 the area of tobacco cultivation in two sub-districts of production centers is $95 \mathrm{Ha}$ and $38 \mathrm{Ha}$ and harvest land of $106 \mathrm{Ha}$ and $99 \mathrm{Ha}$ (BPS, 2021a).

The purpose of the study is as follows: (1) Knowing the potential income of tobacco farmers in Limapuluh Kota Regency, (2) Knowing the feasibility of tobacco farming in Limapuluh Kota Regency when compared to the Provincial Minimum Wage (UMP), and (3) Knowing the minimum land area and selling price of tobacco farming in Limapuluh Kota Regency in order to obtain a decent income.

\section{IMPLEMENTATION METHOD}

This research has been conducted on farmers who cultivate on tobacco in Limapuluh Kota Regency of West Sumatra Province. Selection of locations was done deliberately (purposive) because Limapuluh Kota Regency is the largest producer of tobacco in West Sumatra. Location of research in two sub-districts that became the center of tobacco production, namely Bukit Barisan District and Situjuah Limo Nagari District. Data collection is carried out from September to October 2021.The research method used in this study is a descriptive method where in the collection of data using survey methods.

Total number of tobacco farmers in Situjuah Limo Nagari District amounted to 210 farmers consisting of 5 nagari while Bukit Barisan District amounted to 771 farmers consisting of 4 nagari (BPP, 2021). Then the number of research sampling in each nagari is determined by purposive sampling method. Particular characteristic of the sample are wet leaves, a stand-up sales system and dried leaves. Sample taken was as many as 60 samples consisting of 30 wet tobacco farmers in Situjuah District and 30 dry tobacco farmers in Bukit Barisan District. According to (Sugiyono, 2013) claimed on measuring samples i.e. the size of the feasible in the study is between $30-500$.

The data collected in this study contained two types of data including primary data and secondary data. Primary data is obtained through direct interview methods with tobacco farmers. Interview techniques are conducted using pre-prepared questionnaires. Primary data collected in the study, namely the identity of farmers, information on farming costs, and information on the production and selling price of wet and dry tobacco. Secondary data obtained from related institutions or agencies, including the Central Statistics Agency, the Directorate General of Plantations of the 
Ministry of Agriculture, the Indonesian Tobacco Farmers Association (APTI) of Limapuluh Kota Regency, books, and scientific articles.

Method of data analysis, according to (Suratiyah, 2015) calculation of business income can be formulated as follows:

Description:

$$
\Pi=\mathrm{TR}-\mathrm{TC}
$$

$\Pi \quad=$ Income $(\mathrm{Rp})$

$\mathrm{TR}=$ Total receipt $(\mathrm{Rp})$

$\mathrm{TC} \quad=$ Total cost $(\mathrm{Rp})$

$$
\begin{gathered}
\mathrm{TR}=\mathrm{Py} . \mathrm{Y} \\
\mathrm{TC}=\mathrm{FC}+\mathrm{VC}
\end{gathered}
$$

Description :

$\mathrm{TR} \quad=$ Total receipt $(\mathrm{Rp})$

Py $\quad=$ Production union price $(\mathrm{Rp})$

$\mathrm{Y} \quad=$ Amount of production $(\mathrm{Kg})$

$\mathrm{FC} \quad=$ Fixed cost $(\mathrm{Rp})$

$\mathrm{VC} \quad=$ Variable cost $(\mathrm{Rp})$

Analysis of Feasibility To find out the feasibility of tobacco farming is as follows:

Description :

$$
\mathrm{R} / \mathrm{C}=\mathrm{TR} / \mathrm{TC}
$$

$$
\begin{array}{ll}
\mathrm{TR}(\text { Total Revenue) } & =\text { Total Revenue }(\mathrm{Rp}) \\
\mathrm{TC}(\text { Total Cost }) & =\text { Total Cost of Production }(\mathrm{Rp})
\end{array}
$$

According to (Suratiyah, 2015), the criteria for the feasibility of farming are:

- If $\mathrm{R} / \mathrm{C}>1$ then tobacco farming is efficient, where every expenditure is Rp.1,- generates receipts greater than Rp.1,-

- If $\mathrm{R} / \mathrm{C}<1$ then tobacco farming is inefficient, where every Rp.1,- the costs incurred will result in receipts smaller than Rp.1,-

- If $\mathrm{R} / \mathrm{C}=1$ then tobacco farming is not profitable and not loss (break even).

To analyze the data on the difference between the average income of tobacco farmers in Limapuluh Kota regency obtained from the field with UMP West Sumatra using Z test. Z test is a statistical test to compare the average of 2 variables in a group. The formula for the $\mathrm{Z}$ test according to (Sundayana, 2014) is as follows:

$$
\begin{gathered}
Z_{h}=\frac{\bar{x}-\mu_{0}}{\sigma_{\bar{x}}} \\
\sigma_{\bar{x}} \rightarrow S_{\bar{x}}=\frac{s}{\sqrt{n}} \\
s=\sqrt{\frac{\sum(x-\bar{X})^{2}}{n-1}}
\end{gathered}
$$

Description :

$\bar{x} \quad=$ Average Income of Tobacco Farmers

$\mu_{0} \quad=$ UMP West Sumatra

$\sigma_{\bar{x}} \quad=$ Sample Deviation Standards

$\mathrm{S} \quad=$ Population Deviation Standards

$x_{i} \quad=$ Income - Each Farmer

$\mathrm{n} \quad=$ Number of samples

Hypothesis Testing:

Ho : Tobacco farming income in Limapuluh Kota regency $\geq$ The Minimum Wage of West 
Sumatra Province (UMP).

$\mathrm{H}_{1}$ : Tobacco farming income in Limapuluh Kota regency < The Minimum Wage of West

Sumatra Province (UMP).

Decision:

If $\mathrm{Z}_{\text {hit }} \geq \mathrm{Z}_{\text {tabel }}$, then $\mathrm{H}_{0}$ accepts dan $\mathrm{H}_{1}$ refuses

If $\mathrm{Z}_{\text {hit }}<\mathrm{Z}_{\text {tabel }}$, then $\mathrm{H}_{0}$ refuses dan $\mathrm{H}_{1}$ accepts

Land Area and Selling Price Minimum Analysis

According to (Sidqi, 2021) to find out the minimum land area of tobacco farming in Limapuluh Kota regency in order to be able to meet a decent income for farmers and in accordance with the Provincial Minimum Wage (UMP) of West Sumatra, namely using the formula:

$$
\text { Land Area Minimum }=\frac{\mathrm{UMP}}{\mathrm{P}} \times \text { Average Land Area }
$$

Dimana :

UMP $\quad=$ Provincial Minimum Wage West Sumatera (Rp. 2.484.041,-)

$\mathrm{P} \quad=$ Tobacco Farm Income $(\mathrm{Rp})$

According to (Sidqi, 2021) to find out the minimum selling price of tobacco farming in Fifty Cities regency in order to be able to meet a decent income for farmers and in accordance with the Provincial Minimum Wage (UMP) of West Sumatra, namely using the formula:

$$
\text { Minimum Selling Price }=\frac{(\text { UMP } x \text { business period })+\text { Total Cost }}{\text { Average Production } / \text { Period }}
$$

\section{RESULTS AND DISCUSSION}

\subsection{Potential Tobacco Farming Revenue in Limapuluh Kota District}

\subsubsection{Cost of Tobacco Farming}

Tobacco farming costs in this study include on farm activities (cultivation activities) and off farm (post harvest or processing of tobacco leaves into krosok). Cost is distinguished into fixed costs, namely costs whose magnitude is not influenced by the amount of production, and variable costs are costs whose magnitude is influenced by the magnitude of production. For fixed costs (fixed cost) namely land rental costs, loans and depreciation of tools. While variable costs are the cost of materials including seeds, fertilizers and pesticides, labor costs and processing costs. Tobacco farming costs are costs incurred or taken into account in Limapuluh Kota Regency, especially in two production center sub-districts, namely Bukit Barisan District and Situjuah Limo Nagari District.

Table 1. Average Cost of Wet Tobacco Farming in Situjuah District Limapuluh Kota Regency

\begin{tabular}{clrrr}
\hline No & \multicolumn{1}{c}{ Cost Component } & & Cost (Rp) & Percentage \\
\hline 1. & Fixed Cost (FC) & & & \\
& - Land Rental Cost & $\mathrm{Rp}$ & 336.938 & $8,9 \%$ \\
& - Tools Depreciation & $\mathrm{Rp}$ & 58.889 & $1,6 \%$ \\
& $\quad$ Cost & & & \\
\hline 2. & Variable Cost (VC) & $\mathrm{Rp}$ & 58.000 & $1,5 \%$ \\
& - Seeds Cost & $\mathrm{Rp}$ & 907.713 & $24.1 \%$ \\
& - Fertilizer Cost & $\mathrm{Rp}$ & 108.267 & $2,9 \%$ \\
& - Perticides Cost & $\mathrm{Rp}$ & 2.298 .917 & $61 \%$ \\
\hline - Labor Cost & Total Cost & Rp & $\mathbf{3 . 7 6 8 . 7 2 4}$ & $\mathbf{1 0 0 \%}$ \\
\hline
\end{tabular}

Based on the calculation of table 2 above, it can be known if the cost of wet tobacco farming amounted to $\mathrm{Rp} \mathrm{3,768,724} \mathrm{/} \mathrm{Ha} /$ period and labor costs are the largest costs with a percentage of 
$61 \%$ of the total cost of farming. In line with research (Rizal, 2016) where labor costs became the largest cost component in people's tobacco farming in East Lombok Regency because it was divided into several stages of soil processing and planting. Tobacco farming activities in Limapuluh Kota Regency start from land processing, breeding, seeding, planting, distilling, weeding, heaping, fertilization and disease pest control. As for harvesting for wet selling farmers, tobacco harvesting activities are carried out by traders who buy tobacco harvests and are sold in the form of stems / stands. Soil processing and growing activities are the activities that use the most labor and large costs.

Table 2. Average Cost of Dry Tobacco Farming in Bukit Barisan District Limapuluh Kota Regency

\begin{tabular}{|c|c|c|c|c|}
\hline \multirow{6}{*}{$\frac{\text { No }}{1 .}$} & Cost Component & & Cost (Rp) & Percentage \\
\hline & Fixed Cost $(\mathrm{FC})$ & & & \\
\hline & - Land Rental Cost & $\mathrm{Rp}$ & 116.667 & $3 \%$ \\
\hline & - Tools Depreciation & $\mathrm{Rp}$ & 258.255 & $6 \%$ \\
\hline & Cost & $\mathrm{Rp}$ & 83.333 & $2 \%$ \\
\hline & - Interest Cost & & & \\
\hline \multirow[t]{6}{*}{2.} & Variable Cost (VC) & & & \\
\hline & - Seeds Cost & $\mathrm{Rp}$ & 38.333 & $1 \%$ \\
\hline & - Fertilizer Cost & $\mathrm{Rp}$ & 366.292 & $8 \%$ \\
\hline & - Pesticides Cost & $\mathrm{Rp}$ & 19.205 & $1 \%$ \\
\hline & - Labor Cost & $\mathrm{Rp}$ & 3.411 .667 & $79 \%$ \\
\hline & Total Cost & $\mathbf{R p}$ & 4.343.752 & $100 \%$ \\
\hline
\end{tabular}

Based on the calculation of table 3 above it can be known if the most cost incurred in dry tobacco farming is labor as well as wet selling tobacco with a percentage of 79\%. Similar to research (Dini, 2021) where the highest cost structure in yellow and black tobacco farming is labor costs, with a value of $41.70 \%$ and $44.39 \%$ respectively from the total production cost in Labuhan Haji District of East Lombok Regency. The total cost of dry tobacco in Bukit Barisan District is Rp 4,343,752 / $\mathrm{Ha} /$ period, this is because tobacco leaves that have been harvested still need processing before reaching the final consumer. It can be known the production costs incurred on wet and dry tobacco are different. In the labor production factor, the cost needs incurred are different for wet tobacco and dry tobacco which causes differences in selling prices of both. The cost of producing dry tobacco is greater than the cost of determining the selling price of tobacco in wet form. This is because to produce dry tobacco there is a post-harvest stage that is a process that takes place from wet leaves to dried leaves (krosok / rajangan) to become the final material or product, so additional costs are needed to carry out the drying process.

\subsubsection{Production and Selling Price}

According to (Pradipta, 2017) tobacco that is widely cultivated in Indonesia is Virginia tobacco, native tobacco / rakyat and burley tobacco. Tobacco used in Limapuluh Kota Regency is the original tobacco / rajangan or commonly called rakyat tobacco. The average tobacco production there are two types, namely wet leaf tobacco as much as 5,010 stems and dried leaves as much as $139 \mathrm{~kg}$. There is a difference in the amount of production between dry tobacco and wet tobacco because to produce dry tobacco, the drying process means that tobacco must be dried so as to reduce the water content contained in the tobacco. The lowest tobacco yield rate is generally $10-15 \%$ in the second and third picks whereas, the highest conversion of wet to dry tobacco leaves is generally 25$30 \%$ at the first picking and all depends on what type of tobacco is grown (Sinulingga, 2018).

Table 3. Average Tobacco Production and Selling Price in Limapuluh Kota Regency

\begin{tabular}{ccccr}
\hline No & Tobacco & Production & & \multicolumn{1}{c}{ Selling Price } \\
\hline 1. & Wet Tobacco & $5.010 \mathrm{rod}$ & $\mathrm{Rp}$ & 1.933 \\
\hline 2. & Dry Tobacco & $130 \mathrm{~kg}$ & $\mathrm{Rp}$ & 87.964 \\
\hline
\end{tabular}


Based on table 3, it can be known if production in the form of dry tobacco has a higher selling price than the selling price of wet tobacco. Average selling price of tobacco - rp 1,933 / rod and Rp $87,964 / \mathrm{kg}$, respectively. The selling price in Limapuluh Kota Regency is quite high compared to research (Sinulingga, 2018) which shows that the cost of dry tobacco in Sumbul District of Dairi Regency amounted to Rp 24,291 / kg. But for wet tobacco amounting to Rp 5,285 / kg and the price difference is due to differences in the way of sales where in Limapuluh Kota Regency in the form of stands (rods) not in $\mathrm{kg}$.

\subsubsection{Revenue and Income}

Revenue of farmers on tobacco farming is obtained from the multiplication between the selling price and the amount of production. Price is the value of a product expressed with money. The price of tobacco in the research area varies depending on the way it is sold and the agreement with the merchant. The price and amount of production used by researchers is the average price in the growing season in 2021. Tobacco farming income is the result of farmers revenue each Ha reduced by the total cost incurred each Ha each period. The results of the study (Anwar et al., 2021) the price is very influential on income and the price of virginia tobacco dry tobacco (flue cured virginia) in East Lombok is determined by its quality, the better the quality produced (orange tobacco) the more expensive it will be. But on the contrary, if the dry tobacco produces a lot of lemon tobacco then the price is low and greatly affects farmers' incomes.

Table 4. Average Revenue and Income of Tobacco Farming in Limapuluh Kota Regency

\begin{tabular}{|c|c|c|c|}
\hline No & Component & & \\
\hline \multicolumn{4}{|c|}{ Wet Tobacco } \\
\hline 1. & Revenue & $\mathrm{Rp}$ & 9.563 .533 \\
\hline 2. & Total Cost Production & $\mathrm{Rp}$ & 3.768 .723 \\
\hline 3. & Income each Period & $\mathrm{Rp}$ & 5.794 .810 \\
\hline 4. & Income each Month & $\mathrm{Rp}$ & 1.448 .703 \\
\hline \multicolumn{4}{|c|}{ Dry Tobacco } \\
\hline 1. & Revenue & $\mathrm{Rp}$ & 11.176 .664 \\
\hline 2. & Total Cost Production & $\mathrm{Rp}$ & 4.343 .752 \\
\hline 3. & Income each Period & $\mathrm{Rp}$ & 6.832 .913 \\
\hline 4. & Income each Month & $\mathrm{Rp}$ & 1.708 .228 \\
\hline
\end{tabular}

Based on table 4, it shows that the average revenue of wet and dry tobacco in Limapuluh Kota Regency are Rp 9,563,533/Ha/period and Rp 11,176,664/Ha/period respectively and for the average wet tobacco revenue of Rp 5,794,810/Ha/period of dry tobacco Rp 6,832,913/Ha/period.

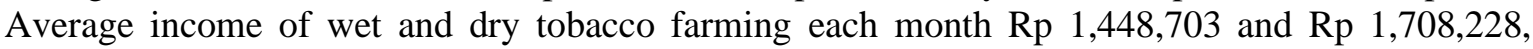
respectively. Tobacco farming in Limapuluh Kota Regency is profitable in terms of income analysis and also has potential when viewed from tobacco farmers who still survive and in terms of tobacco post-harvest processing.

Research (Appau et al., 2019) explains the perspective of farmers in the Philippines and Indonesia that there are 2 categories that represent tobacco farmers in conducting tobacco farming, namely survival and financial context. The survival category consists of 3 sub-categories, namely profit, availability in the market and environmental factors in tobacco cultivation. While in the category of financial context consists of 2 sub-categories, namely access to financial loans and when the lack of capital and savings accumulated. This suggests that tobacco farmers prefer to farm tobacco because of profit revenue, resistance to adverse weather, market availability for tobacco and access to credit. 


\subsection{The feasibility of tobacco farming in Limapuluh City Regency when compared to the Provincial Minimum Wage (UMP).}

Table 5. Feasibility of Tobacco Farming in Limapuluh Kota Regency

\begin{tabular}{cccc}
\hline No & Component & R/C & Z Test $\boldsymbol{\alpha}=\mathbf{5 \%}$ \\
\hline 1. & Wet Tobacco & $2,51>1$ & $-5,94<-1,65$ \\
\hline 2. & Dry Tobacco & $2,57>1$ & $-4,43<-1,65$ \\
\hline
\end{tabular}

Based on the calculations above it is known that wet tobacco farming is worth attempt because the feasibility value of $\mathrm{R} / \mathrm{C}$ is $2.54>1$, then tobacco farming is efficient, where every expenditure is Rp.1,- generates revenue greater than Rp.1,-. For dry tobacco farming are worth attempt because the feasibility value of $\mathrm{R} / \mathrm{C}$ is $2.57>1$, then efficient tobacco farming, where every expenditure is Rp.1,- generates revenue greater than Rp.1,-. Similarly with research (Nining, 2021) stated that the value of R / C tobacco farming in the Cempi Bay Area of Dompu Regency is 2.2 (greater than 1), then the tobacco farming business is said to be worthy of development. Research (E. A. Putri et al., 2015) shows the use of tobacco farming costs in Gunungsari Village maesan district of Bondowoso regency is efficient with an $\mathrm{R} / \mathrm{C}$ ratio of more than one, amounting to 1.81 and research (Sinulingga, 2018) shows the business of dry tobacco and wet tobacco in Dairi Regency deserves to be tried with a value of $\mathrm{R} / \mathrm{C}>1$.

Analysis of revenue each month wet tobacco revenue of Rp 1,448,703 and with UMP West Sumatra amounting to $\mathrm{Rp} 2,484,041$ using the $\mathrm{Z}$ test. The results showed a calculated $\mathrm{Z}$ value of $5.94<\mathrm{Z}$ table -1.65 with a real level $(\alpha)$ of $5 \%$. Based on the hypothesis tests formulated earlier can be concluded if $\mathrm{H} 1$ is accepted and $\mathrm{H} 0$ is rejected, with the conclusion of the average income of tobacco farmers in Limapuluh Kota Regency smaller than $(<)$ The Provincial Minimum Wage (UMP) of West Sumatra. Analysis of income each month of dried tobacco amounted to Rp 1,708,228 with UMP using the $\mathrm{Z}$ test. The results show a calculated $\mathrm{Z}$ value of $-4.43<\mathrm{Z}$ table -1.65 with a real $(\alpha)$ level of 5\%.Based on the hypothesis formulated earlier it can be concluded if $\mathrm{H} 1$ is accepted and $\mathrm{H} 0$ is rejected by the conclusion of the average income of tobacco farmers in Limapuluh Kota Regency is smaller than $(<)$ The Provincial Minimum Wage (UMP) of West Sumatra.

Wet tobacco revenues and dry tobacco each month are smaller than UMP West Sumatra shows that tobacco farming does not have a big impact on farmers' incomes. This is due to fluctuations in the area of tobacco business land even average business, namely $0.16 \mathrm{Ha}$ and 0.25 Ha. Likewise with fluctuations in production as expressed (Aini et al., 2019) that the technical culture of tobacco carried out by farmers in Bukit Barisan District Limapuluh Kota Regency includes breeding activities, soil processing, planting, maintenance, fertilization, eradication of pests and diseases, harvesting and post-harvest. Of these activities only $37.58 \%$ are in accordance with the literature while the remaining $62.42 \%$ is not in accordance with the literature. As well as price fluctuations where farmers only follow the prices given by collecting traders.

Inversely proportional to research (N. A. W. Putri et al., 2018) showed tobacco farming income each respondent of $\mathrm{Rp} 8,966,784.00$ each month. The income is greater than UMK Temanggung Regency of Rp 1,557,000.00 each month. This is because tobacco farmers in Temanggung conduct business cooperation with PT Djarum and according to (Fanani et al., 2015) stated that the existence of partnerships can reduce price risk because partner farmers get price guarantees in accordance with agreed contracts and can reduce production risks faced by partner farmers with capital assistance. Farmers are also given direction and counseling from PT Djarum every time they enter the growing season, so that the results obtained in accordance with the SOP (Standart Operating Procedure) desired by PT Djarum.

3.3 Minimum Land Area and Selling Price of Tobacco Farming in Limapuluh Kota regency in order to Obtain a Decent Income.

Table 6. Minimum Land Area and Selling Price of Tobacco Farming in Limapuluh Kota Regency

\begin{tabular}{|c|c|c|c|}
\hline No & Tobacco Farming & Minimum Land Area & Minimum Selling Price \\
\hline 1. & Wet & $0,43 \mathrm{Ha}$ & $\mathrm{Rp} 2.736 / \mathrm{rod}$ \\
\hline 2. & Dry & $0,23 \mathrm{Ha}$ & $\mathrm{Rp} 109.846 / \mathrm{kg}$ \\
\hline
\end{tabular}


The area of land managed by farmers has different areas depending on the ability of farmers in the procurement of the land. With an average land area of $0.25 \mathrm{Ha}$ for wet tobacco farmers and $0.16 \mathrm{Ha}$ for dry tobacco farmers, it can be said that tobacco farmers in Limapuluh Kota Regency belong to small farmers or narrow land farmers because the land area $<1 \mathrm{Ha}$. The area of land owned by farmers can affect the amount of tobacco production, while the status of land ownership used for farming is their own and some farmers use rented land or revenue sharing.

The area of planting land will affect the production. Land is an important factor of production. The existence of land will affect the small number of farmers' acceptance. With an increasingly large area of land, of course, the plants that will be planted are increasing. If the results planted can be optimal production will certainly affect the income and income of farmers. Based on the calculation of the minimum land area of tobacco farming in Limapuluh Kota Regency in order to obtain a decent income, namely wet tobacco $0.43 \mathrm{Ha}$ while dry tobacco $0.23 \mathrm{Ha}$.

The price of wet and dry tobacco is determined by the collecting merchants and the farmer acts as a price taker. According to (Kusnianto et al., 2018) the oligopsony tobacco market decreases the bargaining position of tobacco farmers. Tobacco farmers do not have direct access to the plant. The process of buying and selling tobacco products is mediated by middlemen / middlemen / middlemen / and wholesalers. This condition results in fluctuations in tobacco prices that harm farmers. Based on the calculation of the minimum selling price in order to obtain a decent income is at the price level of Rp 2,736 / rod for wet tobacco and Rp 109,846 / kg for dry tobacco.

\section{CONCLUSION}

Conclusions from the results and discussions include:

1. Tobacco farming in Limapuluh Kota Regency has the potential to be cultivated can be seen from the average income of wet and dry tobacco Rp 5,794,810 / Ha / period and Rp 6,832,913 / Ha / period.

2. The value of wet and dry tobacco, $\mathrm{R} / \mathrm{C}>1$, indicates that tobacco farmers benefit from farming. But the comparison with the Provincial Minimum Wage (UMP) actually showed different results from R / C, namely the accepted $\mathrm{H} 1$ hypothesis, the left-hand design with the conclusion of tobacco farming income in Limapuluh Kota Regency is smaller than UMP West Sumatra.

3. The minimum land area that farmers must have in tobacco farming is $0.43 \mathrm{Ha}$ and $0.23 \mathrm{Ha}$ for wet and dry tobacco. While the minimum selling price in order to get a decent income is $\mathrm{Rp} 2,736$ / rod for wet tobacco and Rp 109,846 / kg for dry tobacco.

Farmers are expected to streamline their tobacco farming by reducing costs, especially labor costs because they are the largest cost component in their absorption. And farmers are expected to be able to farm on land area in accordance with the results of research calculations in order to obtain a decent income. The government is expected to build business partnerships to be able to help tobacco farmers overcome production, price and market problems.

\section{REFERENCES}

Aini, I., Usman, Y., \& Yusmarni. (2019). Tobacco (Nicotiana tabacum) in District of Bukit Barisan 50 Kota Regency. JOSETA : Journal of Socio Economic on Tropical Agriculture, 1(1), 79-88.

Anwar, M., Prasetyowati, R. E., \& Ahyani, H. (2021). Feasibility Of Virginia Tobacco Farming: Comparative Study on The Flue Cured Processess in East Lombok District. JSEP : Jurnal Sosial Ekonomi Pertanian, 14(1), 1-10.

Appau, A., Drope, J., Witoelar, F., Lencucha, R., \& Chavez, J. J. (2019). Why do farmers grow tobacco? A qualitative exploration of farmers perspectives in Indonesia and Philippines. International Journal of Environmental Research and Public Health, 16(13), 1-11. https://doi.org/10.3390/ijerph16132330

BPP, K. L. K. (2021). Data on the Number of Tobacco Farmers in Limapuluh Kota Regency. BPS. (2021a). Limapuluh Kota in Number. www.bps.go.id

BPS. (2021b). Sumatera Barat in Number. www.bps.go.id/

Dini, S. Y. (2021). Comparative Analysis of Production, Cost and Revenue of Yellow Rajang 
Tobacco and Black Rajang Tobacco In Labuhan Haji District of East Lombok Regency [Universitas Mataram]. http://eprints.unram.ac.id/24364/

Fanani, A., Anggraeni, L., \& Syaukat, Y. (2015). Effect of Partnerships on Tobacco Farming Business Risk in Bojonegoro Regency of East Java Province. Jurnal Manajemen Dan Agribisnis, 12(3), 194-203. https://doi.org/10.17358/jma.12.3.194

Haluan. (2018). Limapuluh Kota is Best Tobacco Producing Cities in West Sumatra. Harian Haluan, 1. www.harianhaluan.com

Hasan, F., \& Darwanto, D. H. (2017). Prospects and Challenges of Madura Tobacco Farming. SEPA: Jurnal Sosial Ekonomi Pertanian Dan Agribisnis, 10(1), 63-70. https://doi.org/10.20961/sepa.v10i1.14108

Kusnianto, Manumono, D., \& Suswatiningsih, T. E. (2018). Tobacco (Nicotiana Tabacum L) farming in Kentengsari Village, Candiroto Subdistrict, Temanggung Regency. Jurnal Masepi, $3(2), 1-20$.

Nining, A. (2021). Analysis of Tobacco Farm Cost and Income in Cempi Bay Area of Dompu Regency [Universitas Mataram]. http://eprints.unram.ac.id/22094/

Pradipta, D. A. (2017). Analysis of Business Income of Tobacco Farmers Partners PT. Djarum in Getasan District of Semarang Regency [Universitas Diponegoro]. http://eprints.undip.ac.id/52961/

Putri, E. A., Suwandari, A., \& Ridjal, J. A. (2015). Income Analysis and Cost Efficiency of Maesan 2 Tobacco Farming in Bondowoso Regency. Jsep, 8(1), 64-69.

Putri, N. A. W., Setiadi, A., \& Santoso, S. I. (2018). Profitability Analysis of Tobacco Farming System of Farmers Partner of PT. Djarum in Bulu Sub District of Temanggung District. J. Agroland, 25(3), 205-213. http://eprints.undip.ac.id/52961/

Rizal, A. (2016). Feasibility of People's Tobacco Farming in East Lombok Regency. Jurnal Ilmiah Rinjani, 4(1), 108-119.

Sidqi, M. S. (2021). Research Guidelines of Plantation Management Study Program. In Politeknik Pertanian Negeri Payakumbuh.

Sinulingga, Y. A. (2018). Financial Analysis of Tobacco in Sumbul District of Dairi Regency. In Analisis. Universitas Sumatera Utara.

Sugiyono. (2013). Qualitative Quantitative Research Methods and R \&D. In Alfabeta.

Suhirman, \& Yusup, J. (2017). Analysis of Tobacco Farming Business Income (Nicotiana tabacum L) Case study in Palon Village, Jepon Subdistrict, Blora Regency, Central Java Province. Universitas Bojonegoro, 1-9.

Sundayana, R. (2014). Education Research Statistics. In Alfabeta.

Suratiyah, K. (2015). Agricultural Sciences Revised edition. In Penebar Swadaya (p. 156).

Suwarto, Octavianty, Y., \& Hermawati, S. (2014). Top 15 Plantation Crops. In Penebar Swadaya (Penebar Sw). 
Volume 1 No 2 (2021)

Analysis Of The Potential Income Of Tobacco (Nicotiana Tabacum L.) Farmers In Limapuluh Kota Regency Of West Sumatera Province

DOI: $10.54443 /$ ijebas.v1i2.74 